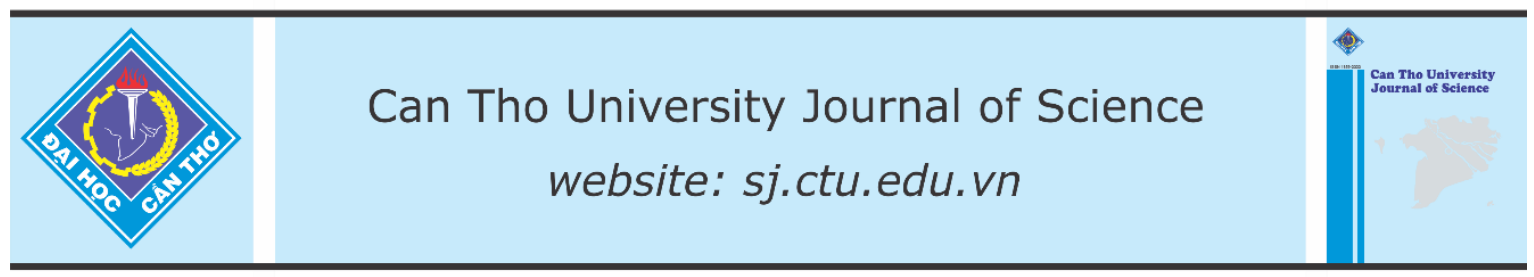

DOI: $10.22144 /$ ctu.jen.2020.025

\title{
Effect of sodium chloride and temperature on biofilm formation and virulence of Flavobacterium columnare isolated from striped catfish (Pangasianodon hypophthalmus)
}

Nguyen Thi Kim $\mathrm{My}^{1 *}$, Tu Thanh Dung ${ }^{1}$, Dong Thanh $\mathrm{Ha}^{2}$ and Channarong Rodkhum ${ }^{2}$

${ }^{1}$ College of Aquaculture and Fisheries (CAF), Can Tho University, Vietnam

${ }^{2}$ Department of Veterinary Microbiology, Faculty of Veterinary Science, Chulalongkorn University, Bangkok 10330, Thailand

*Correspondence: Nguyen Thi Kim My (email: myb1510670@student.ctu.edu.vn)

\section{Article info.}

Received 07 Dec 2019

Revised 30 Jul 2020

Accepted 30 Nov 2020

\section{Keywords}

Biofilm formation, Flavobacterium columnare, immersion, salinity, temperature

\begin{abstract}
This research was conducted to investigate the biofilm formation ability at various salt concentrations and temperatures of Flavobacterium columnare isolated from striped catfish (Pangasianodon hypophthalmus) at Can Tho University. Microtiter plate assay and the in vivo challenge were used to test the virulence of this strain of $F$. columnare for 10 days by immersion method at different salt concentrations (0, 3, 6, 9, 12 and 15 ppt). Results showed that biofilm formation of $F$. columnare was inhibited at 3 and 6 ppt, and stronger reductions were recorded at 9, 12 and $15 \mathrm{ppt}$. In the same trend, the higher temperature, the lower biofilm formation, the highest biofilm formation was at $25^{\circ} \mathrm{C}$ treatment, then it was reduced at 28 and $31^{\circ} \mathrm{C}$, and at $35^{\circ} \mathrm{C}$ the formed biofilm was greatly reduced. Interestingly, there were no statistically significant differences between 28 and $31^{\circ} \mathrm{C}(P>0.05)$. The virulent study found that $100 \%$ fish died after 1- day post challenge at 0 ppt. There were $10 \%$ and $25 \%$ of fish died at 3 and 6 ppt, respectively. No dead fish was found at 9 and 12 ppt. In conclusion, biofilm formation was inhibited at 3 ppt, was almost controlled at 9, 12 and 15 ppt, and was also mostly reduced at $31{ }^{\circ} \mathrm{C}$ at least in the in-vitro study. Furthermore, the virulence of this bacterial strain was controlled $90 \%$ at 3 ppt and completely controlled (100\%) at 9, 12 and 15 ppt.
\end{abstract}

Cited as: My, N.T.K., Dung, T.T., Ha, D.T. and Rodkhum, C., 2020. Effect of sodium chloride and temperature on biofilm formation and virulence of Flavobacterium columnare isolated from striped catfish (Pangasianodon hypophthalmus). Can Tho University Journal of Science. 12(3): 66-72.

\section{INTRODUCTION}

Freshwater fish consumption is recently increasing around the world, in which Pangasianodon hypophthalmus distributed a value of US\$ 2.2 billion for export earnings in 2018 in Vietnam according to the Ministry of Agriculture and Rural Development (mard.gov.vn). Aquaculture production is expected to produce more fish for human consumption directly rather than capture fisheries (Subasinghe et al., 2009). It is necessary to find solutions for a sustainable development in such an important foodproducing sector. Although striped catfish is perhaps the most widely traded fish over the world, it is now facing with many infectious pathogens such as Edwardsiella ictaluri and Aeromonas hydrophila (Crumlish et al., 2010) or a serious pathogen Flavobacterium columnare (Panangala et al., 2007). F. columnare is an agent causing disease on freshwater 
fish worldwide including striped catfish with the clinical signs of skin lesions, fin erosion and gill necrosis (Declercq et al., 2013). The first isolates of $F$. columnare were isolated from aquarium fish such as Koi (Cyprinus carpio), black molly (Poecilia sphenops) and platy (Xiphophorus maculatus) by Decostere et al., (1998). The emergence of columnaris disease on striped catfish currently has leaded high economic loss due to high mortality within commercial hatchery ponds (Tien et al., 2012). The adhesion of bacteria to tissues has been considered as a crucial step in pathogenesis of many infections in animals and human beings (Magarinos et al., 1996). Interestingly, there is an evidence that resilience of biofilm posited in the closed aquaculture systems can act as a source of contagion for farmed fish (Cai et al., 2013).

Biofilms can make up a single or multiple species to colonize biotic or abiotic surfaces, their architecture provides a defense and offers the microbes the spatial proximity and internal homeostasis needed for their growth and differentiation. This makes the bacterial cells within the biofilm much stronger resistant than their planktonic cells to many factors such as antimicrobial treatment, poisons, protozoans and host immunity (Long et al., 2020). It is also considered as the most considerable problem of the biofilms (Mah and O'Toole, 2001). The key advantage of biofilms is their positive influence of solid surfaces on the bacterial activity. This advantage of biofilm has been taken the attention of many researchers in different fields such as water and wastewater treatment and many other biotechnology areas (Lazarova et al., 1995). The effects of temperature have been tested to inhibit the adhesion of Vibrio parahaemolyticus and salmonella enterica at $37^{\circ} \mathrm{C}$ (Song et al., 2016). Moreover, high concentration of salt $(10.5 \% \mathrm{NaCl})$ was significantly inhibited by the adherence of bacterial cells of salmonella enterica (Giaouris et al., 2005).

The objective of this study was to determine an appropriate sodium chloride concentration and temperature level to reduce the biofilm formation of $F$. columnare in order to control columnaris disease outbreaks in striped catfish ponds.

\section{METHODOLOGY}

\subsection{Bacterial strain and culture condition}

Flavobaterium columnare strain was isolated from striped catfish (Pangasianodon hypophthalmus) in Can Tho, Vietnam. Previously, this bacterial strain had been identified as $F$. columnare by PCR method
(Dong et al., 2014). The bacteria were proliferated in Anacker and Ordal (AO) broth for 48 hours at $28^{\circ} \mathrm{C}$ with gentle shaking and stock suspensions were stored in AO broth supplemented with $20 \%$ glycerol at $-80^{\circ} \mathrm{C}$.

\subsection{Bacterial density testing}

Density of the bacteria was measured by plate count method. For more details, a 1/10 dilution had been performed with $1.0 \mathrm{~mL}$ of the bacterial stock and 9.0 $\mathrm{mL}$ of the AO broth in a $150 \mathrm{~mm}$ screw-capped tube with label. Then a pipette had been used to transfer $1.0 \mathrm{~mL}$ of the first sample into new first tube with label of $10^{-1}$, capped and vortexed the tube, then the dilution series was continued by using new pipette and pipet tips for each step until reaching $10^{-8}$. Moreover, $100 \mu \mathrm{L}$ of the bacteria from the last three tubes $\left(10^{-6}, 10^{-7}, 10^{-8}\right)$ were spread onto the surface of $\mathrm{AO}$ agar plates by using sterile pipette and pipet tips, the agar plates were incubated for 2 days at $28^{\circ} \mathrm{C}$ and colonies were counted in each agar plate. Plates with colony number at the range of 30-300 were used only (Arana et al., 2013).

\subsection{Salinity testing by microtiter plate assay}

This test was performed by using the microtiter plate assay from O'Toole (2011) to form biofilms at different salinities, the bacterial stock was incubated for 48 hours in shaker at $28^{\circ} \mathrm{C}$ and microtiter dish was used to produce bacterial biofilm during 48 hours. In details, $90 \mu \mathrm{L}$ of medium broth and $10 \mu \mathrm{L}$ of the bacterial stocks $\left(1.8 \times 10^{8} \mathrm{cfu} / \mathrm{ml}\right)$ were put into each well of the microtiter 96-well plate and was incubated for 2 days at $28^{\circ} \mathrm{C}$ (the optimal temperature of $F$. columnare). Sodium chloride concentrations were tested in this study were of $0,3,6,9,12,15 \mathrm{ppt}$ with 7 replications. The negative control was used $100 \mu \mathrm{L}$ of medium broth and was incubated for 48 hours at $28^{\circ} \mathrm{C}$.

\subsection{Temperature testing by microtiter plate assay}

The assay was prepared as described by O'Toole (2011) and the bacterial biofilm was tested at 25, 28, 31 and $35^{\circ} \mathrm{C}$ with 7 replications. The test was performed by putting $90 \mu \mathrm{L}$ of $\mathrm{AO}$ broth and $10 \mu \mathrm{l}$ of the bacterial stocks $\left(1.8 \times 10^{8} \mathrm{cfu} / \mathrm{ml}\right)$ into each well of the microtiter 96-well plate and the negative control was used $100 \mu \mathrm{L}$ of AO media broth, and was incubated for 48 hours before staining and quantification. 


\subsection{Biofilm detection by staining method}

The formed biofilms had been countinuing with biofilm staining with $0.1 \%$ crystal violet as described by O'Toole (2011). The plate after incubation was turned over and was shaked out all of the liquid. Unattached cells and media components were removed by gently submerging the plate into small tub of water. Then, $125 \mu \mathrm{L}$ of $0.1 \%$ of crystal violet solution was added into each well and the plate was incubated at room temperature for 10-15 mins. After that, the plate was rinsed 3-4 times by submerging the plate into small tub of water and shaking it out. The plate was turned upside down and was dried for few hours or overnight. Finally, the plate was photographed when it dried.

\subsection{Biofilm quantification}

The biofilm were quantified by acetic acid $30 \%$, all of those steps were followed by as in previous study (O'Toole, 2011). Each well of the microtiter plate was added $125 \mu \mathrm{L}$ of $30 \%$ acetic acid to solubilize the crystal violet and the plate was incubated at room temperature for 10-15 mins, then the solubilized CV was transferred to a new microtiter plate for quantification in a plate reader at $570 \mathrm{~nm}$ using $30 \%$ acetic acid in water as the blank.

\subsection{Virulence study by immersion challenge}

The virulence study was conducted with striped catfish ( $P$. hypophthalmus) fingerlings bought from a catfish hatchery in Bangkok, Thailand. The fishes were treated with $1 \% \mathrm{NaCl}$ for around 30 minutes before transfer to acclimation tank to minimize the effects from opportunistic pathogens. Catfish fingerlings $(6-10 \mathrm{~g})$ were acclimated for 3 weeks before experimental challenge, and $F$. columnare strain used in the in-vitro test was used for challenge experiment. Bacterial isolate of $F$. columnare was cultured in $\mathrm{AO}$ broth at $28^{\circ} \mathrm{C}$ with shaking $(150 \mathrm{rpm})$ until reaching the optical density (OD) $\sim 1.0$ at 600 $\mathrm{nm}$ to get expected density of $\sim 10^{8} \mathrm{cfu} / \mathrm{mL}$ (Dong et al., 2015). Then traditional plate count method was performed to identify $\mathrm{cfu} / \mathrm{mL}$. Designed dose for immersion challenge was $6.93 \times 10^{6} \mathrm{cfu} / \mathrm{mL}$ according to the median lethal concentration $\left(\mathrm{LC}_{50}\right)$ tested in striped catfish fingerlings (3-6g) previously (Tien et al., 2012). Fishes were divided into 7 groups: 0, $3,6,9,12,15 \mathrm{ppt}$ (by gradually increased 3 ppt per day) and the control group. In the control treatment, the fishes were immersed with AO broth. Each group was had 3 replicates and immersion duration was 1 hour. After immersion, 10 fishes were transferred into each 100-liter culture tank. The fishes were fed twice per day with commercial feed on the demand, the temperature was maintained around 28$29^{\circ} \mathrm{C}$ during the experiment. Fish mortality had been regularly checked and was recorded for 3 weeks. Fresh dead fish and moribund fish were necropsied and the bacteria were isolated from gills, skin and kidney on Anacker and Ordal (AO) agar plates.

\subsection{Statistics}

One-way analysis of variance (ANOVA) and Duncan test used to determine the significant difference $(\mathrm{P}<0.05)$ in different treatments. Mean and standard error was calculated by Microsoft Excel version 2016.

\section{RESULTS AND DISCUSSION}

\subsection{Bacterial isolation}

The bacterial stock stored in refrigerator at $-80^{\circ} \mathrm{C}$ was isolated from striped catfish with clinical signs of columnaris disease such as gill necrosis, fin erosion, or skin lesions and had been identified by PCR method (Dong et al., 2014). Flavobacterium columnare was recovered in Anacker and Ordal (AO) medium agar plate. The bacterial colonies were recognized easily by naked eyes due to their typical characteristics of yellow rhizoid colonies and adherent deeply into the agar (Welker et al., 2005).

A separated colony was picked up to transfer into AO medium broth and was cultured for 2 days in shaking incubator at $28^{\circ} \mathrm{C}$. A ring of bacteria has been found to adhere strongly to the glass bottle upper layer after several hours of incubation, this phenomenon was showed the strong adherent ability of F. columnare (Decostere et al., 1999). Finally, the bacterial stock was used for biofilm formation.

\subsection{Biofilm production ability at various salinities}

Different biofilm formation of $F$. columnare at various salinities could be observed in Figure 1. The $\mathrm{OD}_{570}$ value was recorded before removing planktonic phase to measure bacterial cell growth and was recorded after removing the planktonic phase to measure formed biofilms.

The formed biofilm was highest at $0 \mathrm{ppt}$ with $\mathrm{OD}_{570}$ value at 0.217 . At treatments $3 \mathrm{ppt}$ and $6 \mathrm{ppt}$, biofilm formation was significantly reduced but no statistically significant differences between two treatments $(\mathrm{P}>0.05)$ with $\mathrm{OD}_{570}$ value at 0.106 at both two treatments. The $\mathrm{OD}_{570}$ value was 0.075 at the control treatment. It could be seen that there was a big gap 
between 0 ppt and 3 ppt, there is a possibility to detect a lower $\mathrm{NaCl}$ concentration to inhibit $F$. columnare biofilms in this gap, a previous study was identified that the adherence of $F$. columnare was inhibited at $1 \mathrm{ppt}$ and the significant decrease of the biofilms was identified from 5 to $14 \mathrm{ppt}$ (Altinok et al., 2001; Cai et al., 2013). In the previous study, the bacterial cell growth was found to be inhibited and only a little amount of biofilm was formed at $0 \mathrm{ppt}$ (Cai et al., 2013) and bacteria were not grown at higher than $0.5 \% \mathrm{NaCl}$ (Bernardet, 2007), this was different with the results of this study. It is maybe because of different bacterial strains.

In the study groups of 9, 12 and $15 \mathrm{ppt}$, cell growth and biofilm were low and there were no significant differences with control group $(\mathrm{P}>0.05)$. Their $\mathrm{OD}_{570}$ value was $0.088 ; 0.073$ and 0.077 respectively. These results are similar to those from Welker et al. (2005) that the growth and adherent ability of $F$. columnare were controlled at 9 ppt.

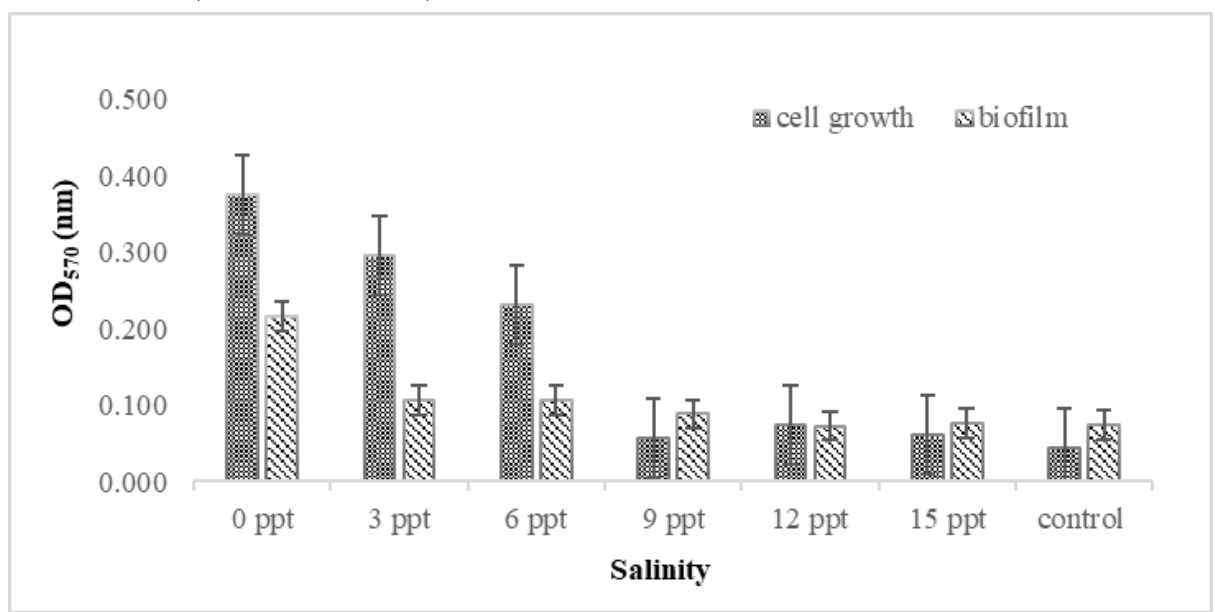

Fig. 1: Biofilm formation and cell growth on microtiter plate for 48 -hour incubation at different salinities

Bacteria recovered at $0,3,6$ ppt groups had been confirmed by streak plate technique but the bacteria were not found at 9,12 and 15 ppt groups (Figure
$2)$. This was confirmed that $F$. columnare was not grown at 9,12 and $15 \mathrm{ppt}$ in the in-vitro test.

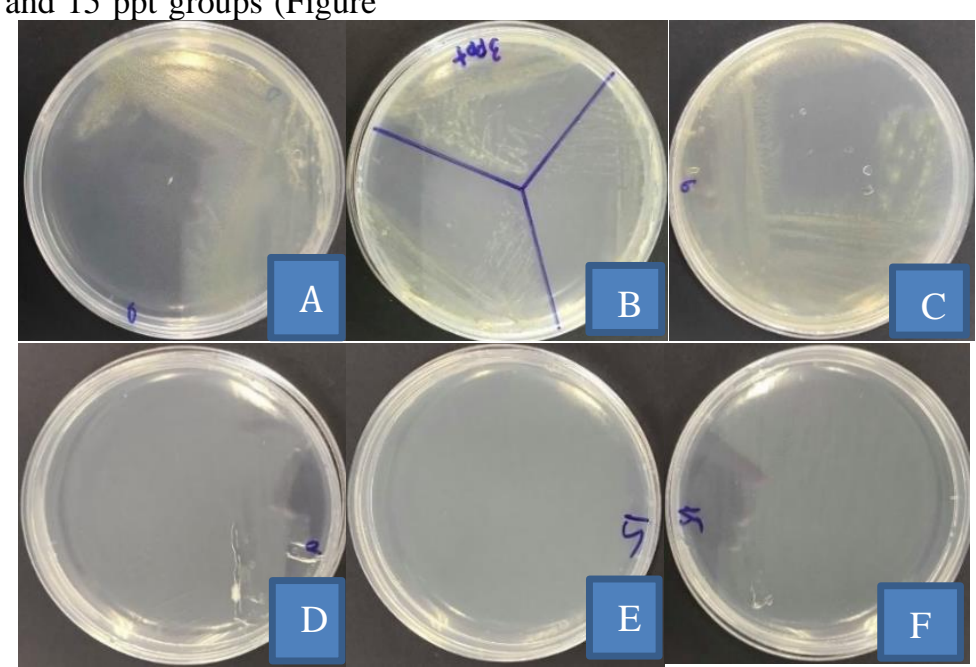

Fig. 2: Cell growth of F. columnare in different salinities; A. in 0 ppt; B. in 3 ppt; C. in 6 ppt; D. in 9 ppt; E. in 12 ppt; F. in 15 ppt 


\subsection{Biofilm production ability on various temperature levels}

The biofilm formation and cell growth of $F$. columnare had been identified after incubated for 2 days (Fig. 3). The biofilm formation and cell growth were inhibited when the temperature was increased. Higher cell growth was observed at 25 and $28^{\circ} \mathrm{C}$ than that at 31 and $35^{\circ} \mathrm{C}$. Based on the $\mathrm{OD}_{570}$ value, there was not significantly different on the bacterial cell growth between 25 and $28^{\circ} \mathrm{C}$ at 0.360 and 0.351 , respectively. Both two temperature levels were in the optimal range of $F$. columnare (Thomas et al., 2004; Cain et al., 2007). At $31^{\circ} \mathrm{C}$, the cell growth was slightly decreased with $\mathrm{OD}_{570}$ value at 0.31 and the cell growth was strongly inhibited in the treatment of $35^{\circ} \mathrm{C}$ with the $\mathrm{OD}_{570}$ value at 0.214 . We were had similar findings with those from the previous study that there was a greatly inhibition of biofilm formation at $35^{\circ} \mathrm{C}$ (Cai et al., 2013).

Biofilm formation was greatly promoted at $25^{\circ} \mathrm{C}$ but it was started to inhibit at $28^{\circ} \mathrm{C}$ with $\mathrm{OD}$ value at 0.352 and 0.261 respectively, no significant difference had been recorded between $28^{\circ} \mathrm{C}$ and $31^{\circ} \mathrm{C}$ $(\mathrm{P}>0.05)$ while biofilm formation at $35^{\circ} \mathrm{C}$ was greatly inhibited with the optical density at 0.139 .

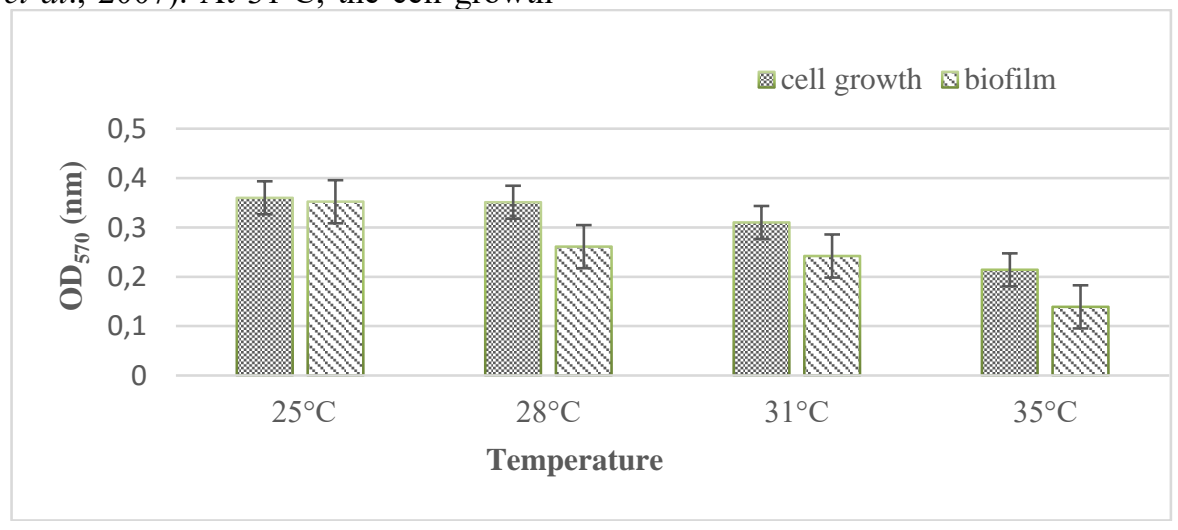

Figure 3. Biofilm formation and cell growth on microtiter plate for $48 \mathrm{~h}$ incubation at different temperatures

The bacterial cells in all treatments were recovered by streak plate technique, this could be said that $F$. columnare could grow at these temperatures. Although the bacterial growth and biofilm production of $F$. columnare were strongly inhibited at $35^{\circ} \mathrm{C}$, it still was not the temperature level to kill the bacteria.

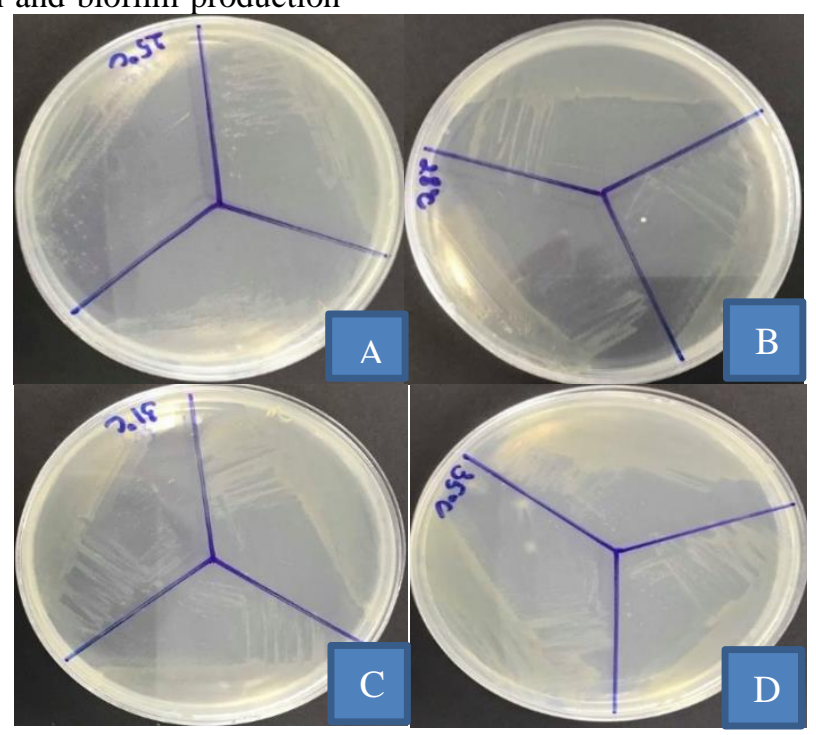

Fig. 4: The cell growth of $F$. columnare in different temperatures; $\mathrm{A}$. in $25^{\circ} \mathrm{C}$; B. in $28^{\circ} \mathrm{C}$; $\mathrm{C}$. in $31^{\circ} \mathrm{C}$; D. in $35^{\circ} \mathrm{C}$ 


\subsection{Bacterial virulence}

All of the fish, prior to challenge, were appeared normal without any sign of disease and no bacteria was recovered from internal organs and external organs of those fish. The $F$. columnare isolate used in the in-vitro test had been challenged with striped catfish (Pangasianodon hypophthalmus) to identify the virulence. The results of fish challenge shown that $100 \%$ of experimental fishes were died after one day post-challenge at $0 \mathrm{ppt}$ treatment. The fishes were died $10 \%$ and $25 \%$ within 4 days of challenge at $3 \mathrm{ppt}$ and $6 \mathrm{ppt}$ treatments, respectively (Table 1). At the end of 14-day challenge period, $F$. columnare was not isolated from survival fishes in all treatments.

There was a correlation between virulence of $\mathrm{F}$. columnare and its adherent ability (Zaldivar, 1985; Decostere et al., 1999). Reduction of fish mortality at 3 and $6 \mathrm{ppt}$ could be related to the inhibition of biofilm formation at these salinities. No fish mortality observed at 9,12 and $15 \mathrm{ppt}$ treatments was also correlated to the greatly inhibition of biofilms in the in-vitro test. The main outcome of this study is that $F$. columnare was quite sensitive to high salinities (Bernardet, 2007). High salinities ( $\geq 3$ ppt) was highly reduced fish mortality, and this could be considered as a prophylactic measure.

Table 1: Percentage of fish mortality at different salinity treatments

\begin{tabular}{cccc}
\hline Salinity (ppt) & Treatment & Time of mortality (day post challenge) & Mortality (\%) \\
\hline 0 & Challenged & 1 & 100 \\
& Control & 3 & 10 \\
3 & Challenged & 3,4 & 10 \\
& Control & $*$ & $*$ \\
6 & Challenged & $2,3,4$ & 25 \\
& Control & $*$ & $*$ \\
9 & Challenged & $*$ & $*$ \\
& Control & $*$ & $*$ \\
12 & Challenged & $*$ & $*$ \\
\hline
\end{tabular}

* No mortality*

\section{CONCLUSIONS}

The biofilm formation of $F$. columnare was inhibited at 3 ppt and 6 ppt. The bacterial biofilm formation was highest at $25^{\circ} \mathrm{C}$ and was reduced at 28 and $31^{\circ} \mathrm{C}$. Cell growth of the bacteria was not recovered at 9, 12 and 15 ppt. Fish mortality was highest at 0 ppt treatment with $100 \%$, while there were lower fish mortalities at 3 and $6 \mathrm{ppt}$ treatments with $10 \%$ and $25 \%$ dead fishes, respectively.

\section{ACKNOWLEDGMENTS}

The authors would like to thanks for the financial support from Chulalongkorn University, Thailand and experimental facilities were provided by Faculty of Veterinary Science and Technology, Chulalongkorn University, Thailand. We also acknowledged the excellent technical and knowledge support from Dr. Nguyen Viet Vuong at Faculty of Veterinary Science and Technology, Chulalongkorn University, Thailand and Mr. Le Minh Khoi at Department of Aquatic Pathology, College of Aquaculture and Fisheries, Can Tho University.

\section{REFERENCES}

Altinok, I. and Grizzle, J.M., 2001. Effects of low salinities on Flavobacterium columnare infection of euryhaline and freshwater stenohaline fish. Journal of Fish Diseases, 24(6): 361-367.

Arana, I., Orruño, M. and Barcina, I., 2013. How to Solve Practical Aspects of

Microbiology 2. Basic Methods for Microbial Enumeration. University of the Basque Country, 10 pages.

Bernardet, J., 2007. Flexibacter columnaris first description in France and comparison with bacterial strains from other origins. Diseases of Aquatic Organisms, 6(1): 37-44.

Cai, W., De La Fuente, L., Arias, C.R., 2013. Biofilm formation by the fish pathogen Flavobacterium columnare: development and parameters affecting surface attachment. Applied and Environmental Microbiology, 79(18): 5633-5642.

Cain, K.D., LaFrentz, B.R., 2007. Laboratory Maintenance of Flavobacterium psychrophilum and Flavobacterium columnare. Current Protocol in Microbiology. Chapter 13. Unit 13B.1.

Crumlish, M., Thanh, P.C., Koesling, J., Tung, V.T., Gravningen, K., 2010. Experimental challenge studies in Vietnamese catfish, Pangasianodon 
hypophthalmus (Sauvage), exposed to Edwardsiella ictaluri and Aeromonas hydrophila. Journal of Fish Diseases, 33(9): 717-722.

Declercq, A.M., Haesebrouck, F., Van den Broeck, W., Bossier, P., Decostere, A., 2013. Columnaris disease in fish: a review with emphasis on bacterium-host interactions. Veterinary Research, 44(1): 1-17.

Decostere, A., Haesebrouck, F., Turnbull, J. F., Charlier, G., 1999. Influence of water quality and temperature on adhesion of high and low virulence. Journal of Fish Diseases, 22(1): 1-11.

Dong, HT., LaFrentz, B., Pirarat, N., Rodkhum, C., 2014. Phenotypic characterization and genetic diversity of Flavobacterium columnare isolated from red tilapia, Oreochromis sp., in Thailand. Journal of Fish Diseases, 38(10): 901-913.

Dong, HT., Nguyen, V.V., Phiwsaiya, K., Gangnonngiw, W., Withyachumnarnkul, B., Rodkhum, C., Senapin, S., 2015. Concurrent injections of Flavobacterium columnare and Edwardsiella ictaluri in striped catfish, Pangasianodon hypophthalmus in Thailand. Aquaculture, 448: 142-150.

Giaouris, E., Chorianopoulos, N., Nychas, G-J,E., 2005. Effect of temperature, $\mathrm{pH}$, and water activity on biofilm formation by Salmonella enterica Enteritidis PT4 on stainless steel surfaces as indicated by the bead vortexing method and conductance measurements. Journal of food protection, 68(10): 2149-2154.

Lazarova, V., Manem, J., 1995. Characterization and activity analysis in water and wastewater treatment. Pergamon, 29(10): 2227-2245.

Long, Lexin., Wang, Ruojun., Chiang, Yin, Ho., Li, Yong-Xin., Chen, Feng., Qian, Pei-Yuan., 2020. A potent antibiofilm agent inhibits and eradicates mono- and multi- species biofilms. BioRxiv, 2020.03.25.009126.

Mah, T.-F.C., O'Toole, G.A., 2001. Mechanisms of biofilm resistance to antimicrobial agents. Trends in Microbiology, 9(1): 34-39.
Magarinos, B., Romalde, J, L., Noya, M., Barja, T,L., Toranzo, A,E., 1996. Adherence and invasive capacities of the fish pathogen Pasteurella piscicida. FEMS Microbiology Letters, 138(1): 29-34.

O'Toole, George, A., 2011. Microtiter dish biofilm formation assay. Journal of Visualized Experimens, 47: 2437.

Panangala, V., Shoemaker, C., van Santen, V., Dybvig, K., Klesius, P., 2007. Multiplex-PCR for simultaneous detection of 3 bacterial fish pathogens, Flavobacterium columnare, Edwardsiella ictaluri, and Aeromonas hydrophila. Diseases of Aquatic Organisms, 74(3): 199-208.

Subasinghe, R., Soto, D., Jia, J., 2009. Global aquaculture and its role in sustainable development. Reviews in Aquaculture, 1(1): 2-9.

Song, X., Ma, Y., Fu, J., Zhao, A., Guo, Z., Malakar, K., Pan, Y. and Zhao, Y., 2016.

Effect of temperature on pathogenic and non-pathogenic Vibrio parahaemolyticus biofilm formation. Food Control, 73: 485-491.

Tien, N., Dung, T., Tuan, N., Crumlish, M., 2012. First identification of Flavobacterium columnare infection in farmed freshwater striped catfish Pangasianodon hypophthalmus. Diseases of Aquatic Organisms, 100(1): 83-88.

Thomas, S. and Goodwin, A.E., 2004. Morphological and genetic characteristics of Flavobacterium columnare isolates: Correlations with virulence in fish. Journal of fish diseases, 27(1): 29-35.

Welker, T., Shoemaker, C., Arias, C., Klesius, P., 2005. Transmission and detection of Flavobacterium columnare in channel catfish Ictalurus punctatus. Diseases of Aquatic Organisms, 63(2-3): 129-138.

Zaldivar, M., 1985. Attachment of the pathogen Flexibacter columnaris to fish cells. Master thesis. Oregon State University, Corvallis, OR, USA. 